\title{
Effects of Ginseng Berry Water Extract on the Polysaccharide Hydrolysis of Extracellular Enzymes and Intracellular PTP1B and AKT1
}

\author{
Eun-Jeong Kwon ${ }^{1}$, Sugyeong Hong ${ }^{1}$, Moon-Moo Kim ${ }^{1}$, Joo Wan $\mathrm{Kim}^{2}$, Deok Won Kim ${ }^{3}$ and \\ Kyung Tae Chung ${ }^{3 *}$
}

\author{
${ }^{1}$ Department of Chemistry, Dong-Eui University, Busan 614714, Korea \\ ${ }^{2}$ Bioport Korea Ltd, Busan 619-912, Korea \\ ${ }^{3}$ Department of Clinical Laboratory Science, Dong-Eui University, Busan 614-714, Korea
}

Received May 26, 2014 /Revised August 21, 2014 /Accepted September 19, 2014

\begin{abstract}
Ginseng has been known to be highly effective for health as a traditional medicinal herb. Ginseng berry, or fruit of ginseng, contains ginsenoside, saponin, polyphenol, polyacetylene, alkaloid, etc. as the main compounds as does ginseng. The aim of this study is to evaluate any effect of ginseng berry water extract (GBE) on diabetic-associated molecules, such as enzymes, which are responsible for the glucose entry of the cells and the insulin receptor signaling molecules using HepG2 cells. Therefore, two enzymes, a-amylase and a-glucosidase, were selected and assayed for their activities in the presence of GBE in vitro. These two enzymes are responsible for producing glucose from dietary starch. Protein-tyrosine phosphatase 1B (PTP1B) and Akt1 are key proteins in the insulin receptor signaling pathway. These two intracellular signaling molecules were investigated for their expression levels in HepG2 cells after insulin and GBE treatment. GBE, at concentrations up to $1,000 \mu \mathrm{g} / \mathrm{ml}$, did not exert any inhibitory effect on a-amylase and a-glucosidase. It was observed that the expression level of PTP1B was increased by insulin and the $25 \mu \mathrm{g} / \mathrm{ml} \mathrm{GBE}$ treatment enhanced the PTP1B level. However, GBE at a concentration of $200 \mu \mathrm{g} / \mathrm{ml}$ reduced the expression level of PTP1B. In the case of Akt1, the Akt1 level by insulin was decreased by GBE treatment. These data suggest that the water extracts of ginseng berry have an influence on intracellular signaling by insulin.
\end{abstract}

Key words : Diabetes, ginseng berry, gluconeogenesis, protein-tyrosine phosphatase 1B (PTP1B)

\section{서 론}

\section{오래 전부터 우리나라 및 중국 등 아시아 전역에서 자양강} 장제로 널리 알려진 한약재인 인삼에는 saponin, polyphenol, polyacetylene, alkaloid, 다당체 등이 많이 포함되어 있어 항산 화 효과뿐만 아니라 항노화, 항염증, 면역증강, 혈압강하 등 다양한 효능을 가지고 있는 것으로 알려져 있다. 뿐만 아니라 한국인삼을 포함한 중국산, 미국산 인삼 등에서 항암 효과에 대한 활발한 연구가 진행되어 왔으며, 추가적으로 항당뇨 효 과입증을 위한 연구가 현재 진행되고 있다 $[2,4,9]$. 인삼의 항 당뇨 연구는 인삼 식이 동물을 이용하여 임상적 혈액지표 분 석을 통해 기능성을 확인하고 있으며, 정제된 gensenoside를 식이하는 방법이 또한 사용되고 있다[15]. 보고된 연구에 따르 면 인삼열매에는 사포닌 함량이 인삼 뿌리보다 높기 때문에

\footnotetext{
*Corresponding author

Tel : +82-51-890-2681, Fax : +82-51-890-2622

E-mail : kchung@deu.ac.kr

This is an Open-Access article distributed under the terms of the Creative Commons Attribution Non-Commercial License (http://creativecommons.org/licenses/by-nc/3.0) which permits unrestricted non-commercial use, distribution, and reproduction in any medium, provided the original work is properly cited
}

우수한 효과를 나타내는 것으로 알려져 있다[14, 20].

인체는 해당과정 및 당 신생 과정을 통해 체내 혈당을 일정 하게 유지하여 정상적인 대사활동을 할 수 있게 한다[1]. 이러 한 과정이 정상적으로 이루어지지 않고 혈당조절이 제대로 유지되지 않는 것을 당뇨라 한다. 당뇨는 신장 기능의 저하, 동맥경화, 망막 출혈로 인해 시력 저하, 말초신경병증 등 다양 한 합병증을 유발하기 때문에 더욱 위험한 질병으로 알려져 있다 $[3,5]$. 당뇨는 원인에 따라 크게 insulin 의존성 당뇨인 1형과 insulin 비 의존성 당뇨인 2형으로 나뉜다. 그 중에 전체 당뇨의 $90 \%$ 에 해당하는 2 형당뇨는 간, 근육, 지방조직에서 insulin에 대한 저항성으로 인해 insulin 작용이 정상적으로 작 동하지 않아 고혈당이 지속되어 유발된다[19]. 또한, vitamin $\mathrm{A}$ 수송 단백질인 retinol-binding protein 4 의 혈액 내 증가가 실험동물과 사람에게서 전신적인 인슐린 저항성을 유발하는 요인이 될 수 있다는 보고는 당뇨병 유발이 다양한 원인에 의해서 일어날 수 있음을 제시하고 있다[22]. $\beta$-cell에서 분비 된 insulin은 insulin receptor (IR)에 결합하여 insulin receptor signaling (IRS) pathway를 통하여 포도당 생성을 억제시키고 저장을 촉진한다[12, 13, 17]. Protein-tyrosine phosphatase 1B (PTP1B)의 경우 IRS 경로에서 IR을 억제시켜 glucose 생성을 촉진시킨다[10]. Akt1은 IRS pathway의 중요한 분자로서 세포 
내 포도당 조절에 관여한다[8]. 현재까지의 항당뇨 연구는 주 로 a- glucosidase와 a-amylase 효소활성의 억제에 초점을 맞 추었으며, 이들 효소의 억제물질 중 잘 알려진 대표적인 성분 으로는 acarbose와 voglibose 등이 보고 되었다[21]. 하지만 인슐린 저항성에 대한 이러한 acarbose와 같은 당뇨치료제들 은 설사 및 복부팽만감등의 부작용이 보고되고 있어 안정성 등의 이유로 사용이 제한되고 있는 실정이다. 최근의 연구는 좀더 안정적인 PTP1B억제를 target으로 한 연구가 진행되고 있다[11]. 인삼열매를 이용한 항당뇨에 대한 연구는 현재 몇몇 연구가 보고되어 있으나 아직까지는 활발하지 못하다. 본 연 구는 인삼열매의 추출물이 당뇨와 관련된 효소와 인슐린 신호 전달물질에 어떤 영향을 주는가에 대한 결과를 보고하고자 한다.

\section{재료 및 방법}

\section{시약 및 추출물의 제조}

세포배양을 위한 Dulbecco's Modified Eagle's Medium (DMEM), trypsin-EDTA, penicillin $(10,000 \mathrm{U} / \mathrm{ml}) /$ streptomycin $(10,000 \mu \mathrm{g} / \mathrm{ml}) /$ amphotericin $(2,500 \mu \mathrm{g} / \mathrm{ml})$, fetal bovine serum (FBS) 시약은 Gibco BRL, Life Technologies (Paisley, Scotland)로부터 구입하였다. HepG2 cell line은 ATCC (American Type Culture Collection, USA)로부터 구입 하였고, a-amylase, a-glucosidase, MTT reagent, agarose 등의 시약은 Sigma Chemical Co. (St. Louis, MO, USA)로부터 구입 하였다.

인삼열매 추출물을 제조하기 위해 한국인삼열매공사(대전 광역시)에서 구매한 4-5년생 생(生)인삼 열매에서 분리한 종자 를 $60^{\circ} \mathrm{C}$ 에서 24 시간 건조 한 후 총량에 대하여 10 배의 물을 가하여 $75^{\circ} \mathrm{C}$ 에서 9 시간 동안 열수 추출한 다음 여과하였다. 여과한 추출액(Ginseng berry extract, $\mathrm{GBE}$ )을 동결건조 과정 을 거쳐 파우더로 생산하여 물에 일정한 농도로 희석하여 실 험에 사용하였다.

\section{GBE에 함유된 Gensenoside 분석}

$\mathrm{GBE}$ 내에 함유된 ginsenoside는 C18 column (Interstil ODS-2, $150 \times 4.6 \mathrm{~mm}, 5 \mu \mathrm{m}$, GL Science Inc.)을 사용하였고, acetonitrile 용매로 18 50\% gradient와 $1 \mathrm{ml} / \mathrm{min}$ flow rate 조건에서 Waters사의 Alliance HPLC (Milford, MA, USA)로 분석하였다. 표준 ginsenoside는 Sigma Chemical Co.에서 구 입하였다.

\section{세포배양과 MTT assay}

$\mathrm{HepG} 2$ 세포는 $5 \% \mathrm{CO}_{2}$ 및 $37^{\circ} \mathrm{C}$ 에서 $95 \%$ 이상의 습도를 유지한 배양기에서 $10 \%$ fetal bovine serum, $2 \mathrm{mM}$ glutamine 과 $100 \mu \mathrm{g} / \mathrm{ml}$ penicillin-streptomycin을 포함하는 DMEM 배
지에서 배양하였다. HepG2 세포에 대한 GBE의 세포독성을 Hansen, et al [7]의 방법에 따라 MTT (3-(4,5-dimethyl-2-yl)2,5-diphenyltetrazolium bromide)를 이용하여 측정하였다.

\section{$a^{-}$-Amylase 저해 활성}

시료의 a-amylase 저해활성은 환원당 분석법을 응용하여 효소원으로 돼지 유래 amylase를 사용하였고, 기질로서 $0.5 \%$ starch를 이용하여 효소활성을 측정하였다. 간단히 설명하면, $1.8 \mathrm{U} / \mathrm{ml}$ 효소액 $50 \mu \mathrm{l}$, 농도 별 시료 $50 \mu \mathrm{l}, 0.5 \%$ starch 100 $\mu \mathrm{l}$, potassium phosphate buffer (pH6.8) $50 \mu 1$ 와 혼합하여 37 ${ }^{\circ} \mathrm{C}$ 에서 20 분간 incubation한 후 $48 \mathrm{mM} \mathrm{DNS}$ 발색시약 (3,5-dinitrosalicylic acid and 30\% sodium potassium tartarate in $0.5 \mathrm{M} \mathrm{NaOH}) 250 \mu \mathrm{l}$ 를 넣고 $100^{\circ} \mathrm{C}$ 에서 10 분간 꼻여 발색 시킨 후 충분히 냉각시켰다. 이 반응액에 3 배량의 물을 가하고 잘 교반한 후 $540 \mathrm{~nm}$ 에서 흡광도를 측정하였다. 이때 활성 비교를 위하여 a-amylase 저해제로 알려진 acarbose를 사용하였다. 효소활성의 억제율은 다음 식에 의하여 산출하였 다.

a-Amylase 저해활성 $(\%)=(1-$ (시료처리군의 흡광도/대조 군의 흡광도) $) \times 100$

\section{$a-G l u c o s i d a s e$ 저해 활성}

a-Glucosidase 저해활성은 nitrophenol 분석법을 응용하여 측정하였다. $0.2 \mathrm{U} / \mathrm{ml}$ 돼지 유래 a-glucosidase 효소액 $50 \mu \mathrm{ll}$, $12 \mathrm{mM}$ p-nitrophenyl-a-D-glucopyranoside $100 \mu \mathrm{l}$, 농도 별 시료 $50 \mu \mathrm{l}$ 및 $0.1 \mathrm{M}$ potassium phosphate buffer (pH6.8) 50 $\mu 1$ 와 혼합하여 $37^{\circ} \mathrm{C}$ 에서 20 분간 incubation한 후 $0.1 \mathrm{M} \mathrm{NaOH}$ $100 \mathrm{\mu l}$ 를 가하여 반응을 정지시키고 $405 \mathrm{~nm}$ 에서 흡광도를 측 정하였다. 이때 활성 비교를 위하여 acarbose를 사용하였다. 효소활성의 억제율은 다음 식에 의하여 산출하였다.

$a-G l u c o s i d a s e$ 저해활성 $(\%)=(1-$ (시료처리군의 흡광도/대 조군의흡광도) $) \times 100$

\section{Western blot analysis}

$10 \mathrm{nM}$ 인슐린 또는 $10 \mathrm{nM}$ 인슐린과 $\mathrm{GBE}$ 농도 별 시료를 처리한 HepG2 세포에 세포용해 완충용액 $(50 \mathrm{mM}$ Tris - HCl, $\mathrm{pH} 7.5,0.4 \%$ Nonidet P-40, $120 \mathrm{mM} \mathrm{NaCl}, 1.5 \mathrm{mM} \mathrm{MgCl}$, $2 \mathrm{mM}$ phenylmethylsulfonyl fluoride, $80 \mu \mathrm{g} / \mathrm{ml}$ leupeptin, $3 \mathrm{mM} \mathrm{NaF}$ and $1 \mathrm{mM} \mathrm{DTT}$ )을 첨가하여 $4{ }^{\circ} \mathrm{C}$ 에서 30 분 동안 처리하였다. $10 \mu \mathrm{l}$ 의 세포 용해액(단백질 함량 $200 \mu \mathrm{g}$ )을 $10 \%$ acrylamide gel에서 전기영동 후 단백질을 전기적으로 nitrocellulose membrane으로 전이 시켰다. 그 다음 $10 \% \mathrm{skim}$ milk 를 nitrocellulose membrane에 전처리하고 목적 단백질에 대 한 1차 항체 anti-PTP1B, anti-Akt1, anti-beta-actin (Santa Cruz Biotechnology Inc., Santa Cruz, USA)을 처리한 다음, 2차 항체 처리 후, chemiluminescent ECL kit (Amersham 
Pharmacia Biotech, Piscataway, USA)를 사용하여 목적 단백 질을 검출하였다. Western blot의 각 band는 LAS3000 ®image analyzer (Fuji film Life Science, Tokyo, Japan)를 이 용하여 관찰하였다.

\section{통계처리}

각 실험은 3 회 반복실험을 통하여 얻은 결과를 각각의 시료 농도에 대해 평균표준편차로 나타내었다. 각 시료 농도군에 대한 유의검정은 대조군과 비교하여 Student's $t$ test 한 후 통계적 유의성을 얻었다.

\section{결과 및 고찰}

\section{$\mathrm{GBE}$ 에 함유된 Gensenoside, Rd와 Rg3}

당뇨병은 insulin 분비에 이상이 생기거나 insulin에 대한 저항성으로 인하여 체내혈당조절이 제대로 되지 않는 질병을 말한다. 보통 정상수준에서보다 높은 혈당이 지속되며 소변으 로 당 배출이 일어난다. 당뇨병환자가 증가하고 있는 가운데 최근 현대인들의 식생활이 서구화로 되면서 비만으로 인한 당뇨환자들 또한 증가하는 추세이다. 인삼의 항당뇨 기능은 여러 논문에서 효능이 있음을 보고 하고 있으며, 인삼이 함유 하고 있는 gensenoside Rb1, Rg1, Re, Rg3, Rh2 등에 기인 한다 고 보고 되었다[15]. 그러나 인삼의 열매 역시 인삼과 같은 동 일한 기능을 가지고 있는지에 대해서는 상대적으로 연구가 적다. 최근 인삼 열매의 항당뇨 연구에서 in vivo 인슐린의 농 도 등이 향상되는 결과가 나타났으나 표적분자에 대한 결과는 없었다[16]. 본 연구는 인삼 열매의 기능성을 당뇨와 관련된 세포 외 및 내 분자에 어떤 영향을 미치는 가를 in vitro 모델에 서 조사하였다. 본 연구에서 인산 열매의 추출은 물을 사용하 였다. 열수 추출물(GBE) 내에 함유된 gensenoside를 HPLC로 분석하였을 때 $\mathrm{Rd}$ 와 $\mathrm{Rg} 3$ 가 존재하는 것을 확인하였고, $\mathrm{Rd}$ 의 함유량이 월등히 높게 나타났다(Fig. 1). 이런 Rd와 Rg3의 양 적인 차이 결과는 앞서 보고된 것과 유사하였으나, 다른 종류 의 gensenoside는 검출되지 않은 것은 추출용매가 물이어서 $70 \%$ 에탄올 추출에서 검출되는 gensenoside profile과는 차이 가 있었다[16].

\section{$a-A m y l a s e$ 와 a-Glucosidase 활성에 대한 GBE의 저해} 효과

인체는 음식을 섭취하게 될 경우 소화과정을 통하여 포도당 흡수를 하게 된다. 이러한 과정에서 a-amylase와 a-glucosidase 효소가 촉매역할을 한다. a-amylase는 구강 내의 타액에 포함되어 있는 소화효소로서 녹말 등의 glucan을 분해하는 효소이며[19], a-glucosidase는 소장의 내벽에서 분비되는 효 소로서 소장에서의 탄수화물 및 포도당의 분해를 도와 체내 당 흡수를 용이하게 한다. 본 연구에서는 이러한 역할을 하는
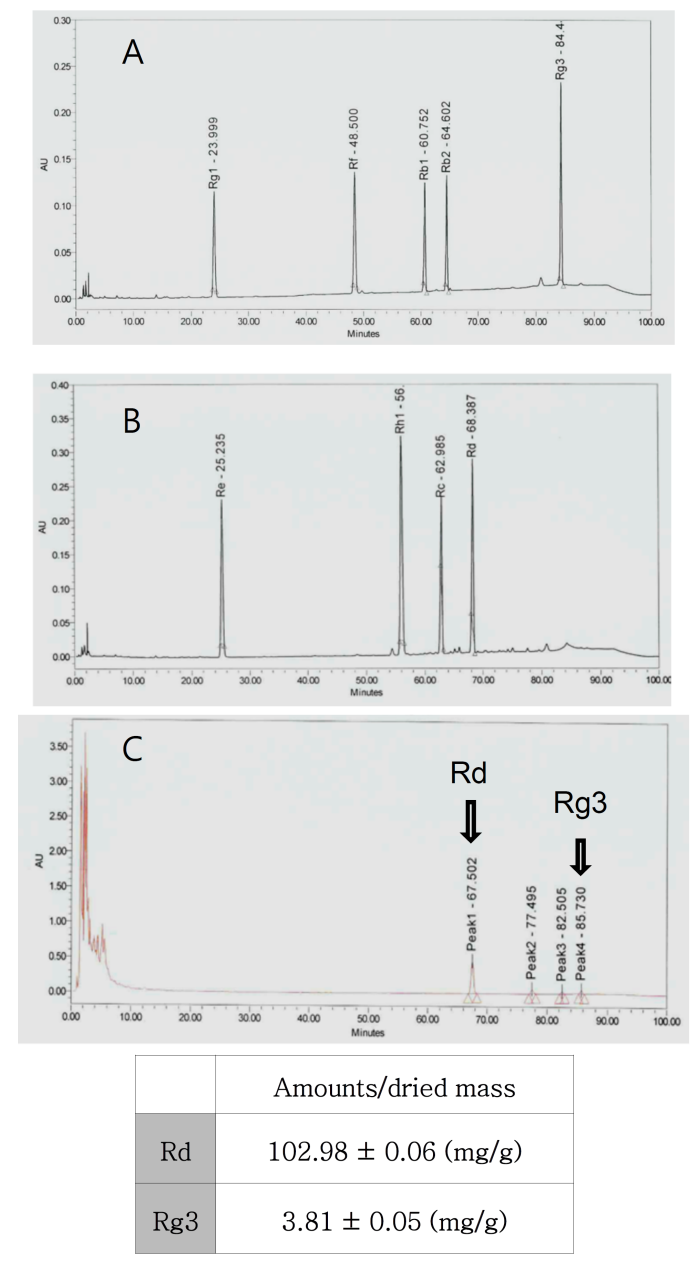

Fig. 1. HPLC elution profile of GBE and standard ginsenosides. GBE was analyzed by HPLC and ginsenosides in GBE were identified by comparing retention times of each standard ginsenosides. A and B show HPLC elution profile of standard ginsenosides and C shows HPLC elution profile of GBE. Amounts of identified ginsenosides, $\mathrm{Rd}$ and Rg3, in GBE dried mass were estimated with standard curves of standard $\mathrm{Rd}$ and $\mathrm{Rg} 3$.

a-glucosidase와 a-amylase 효소 활성에 대한 GBE의 저해효 과를 조사하기 위해 a-amylase와 a-glucosidase 활성저해 실 험을 실시하였다. Fig. 2에서 보는 바와 같이 GBE는 양성대조 군인 acarbose와 비교하여 a-amylase와 a-glucosidase 모두에 서 효소활성 저해효과가 없는 것으로 나타났다.

\section{세포성장에 대한 $\mathrm{GBE}$ 의 영향}

간(Liver)은 췌장에서 분비된 인슐린의 중요한 표적 장기로 서 인슐린에 의해 혈액 내 포도당을 흡수하여 glycogen으로 저장을 한다. 따라서, 간 유래 세포인 HepG2를 이용하여 GBE 의 인슐린 신호전달의 영향을 알아보기 위해 우선적으로 $\mathrm{HepG} 2$ cell에 대한 $\mathrm{GBE}$ 의 세포독성을 MTT assay로 조사하였 다. Fig. $3 \mathrm{~A}$ 에서 보는 바와 같이 $\mathrm{GBE}$ 는 대조군과 비교하였을 

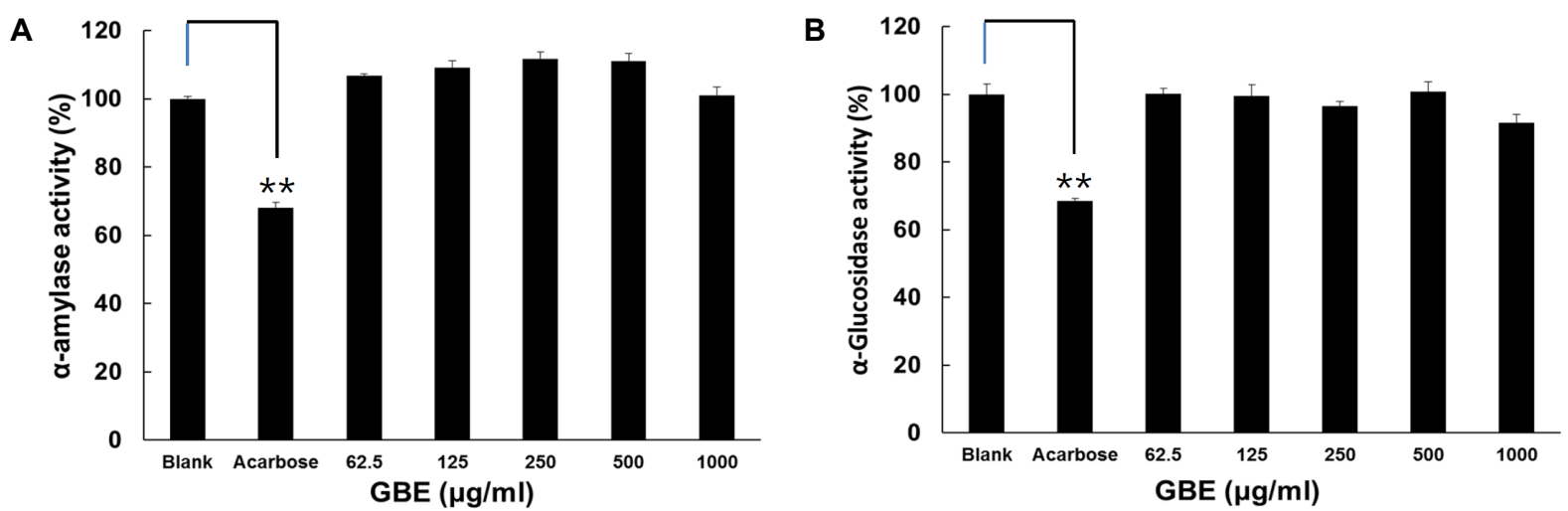

Fig. 2. Effect of GBE on a-amlyase and a-glucosidase activity. GBE was added to a-amlyase (A) and a-glucosidase (B) at the indicated concentrations and activities of each enzyme was measured as described in Materials and Methods. Acarbose at $10 \mu \mathrm{g} / \mathrm{ml}$ was used as a positive control. Data are given as means of values \pm SD from three independent experiments. ${ }^{* *} p<0.01$ versus blank.

A

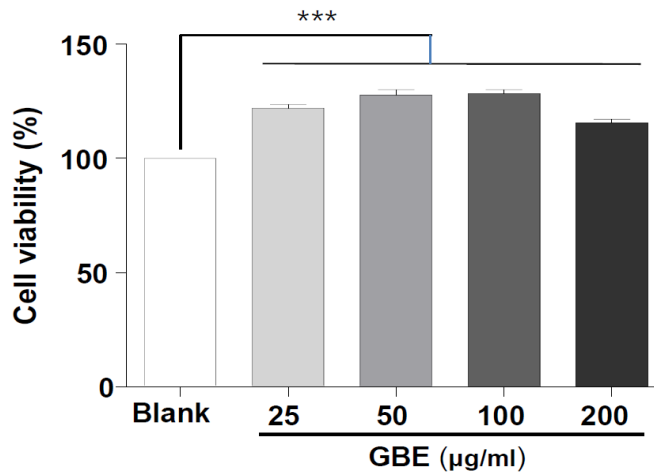

B

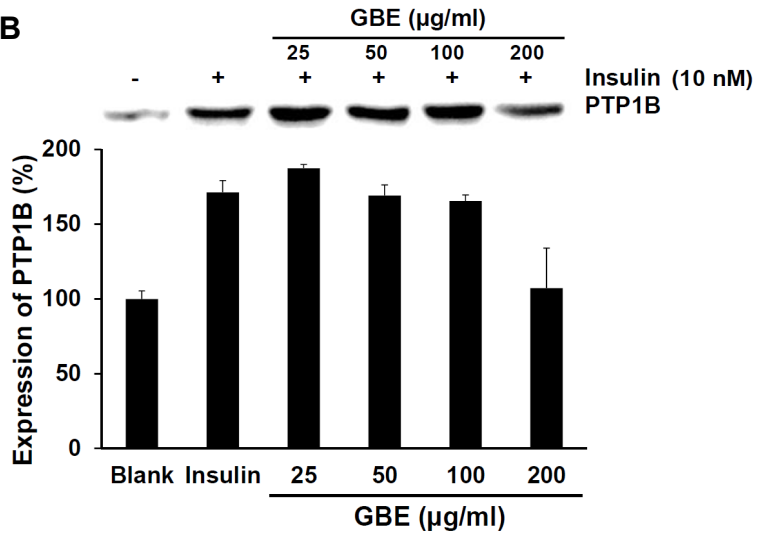

C

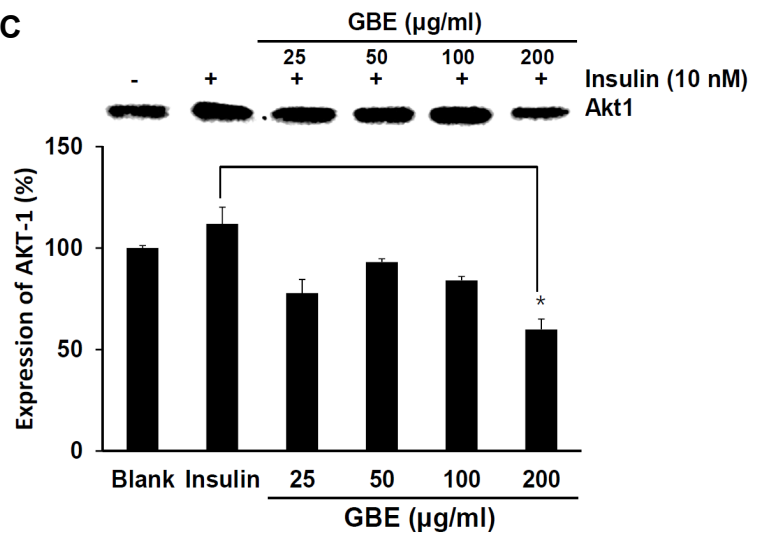

Fig. 3. Effect of GBE on viability of HepG2 cells and protein expressions of PTP1B and Akt1 in HepG2 cells. The cells were treated with GBE at 25, 50, 100 and $200 \mu \mathrm{g} / \mathrm{ml}$. Cell viability was determined by MTT assay after $24 \mathrm{hr}(\mathrm{A})$. Western blot analysis of cell lysates was performed using anti-PTP1B antibody (B) and anti-Akt1 antibody (C) as indicated. Data are given as means of values $\pm \mathrm{SD}$ from three independent experiments. ${ }^{*} p<0.05$ versus insuline, ${ }^{* * *} p<0.001$ versus blank.

때 $200 \mu \mathrm{g} / \mathrm{ml}$ 농도까지 어떠한 독성도 나타나지 않았으며, 오 히려 $\mathrm{GBE}$ 에 의해 세포성장이 다소 증가하는 것으로 나타났다.

HepG2 세포에서 Insulin Signaling 관련된 단백질의 발 현에 대한 $\mathrm{GBE}$ 의 효과

당뇨병은 1형과 2형으로 구분되며 전체 당뇨병의 $90 \%$ 를
차지하고 있는 2형 당뇨병의 경우 insulin저항성에 의한 당뇨 병으로 알려져 있다. $\beta$-cell에서 insulin이 분비되면 insulin receptor (IR)에 결합하여 insulin receptor signaling (IRS)을 통 해 gluconeogenesis를 억제하여 식사 후 증가한 혈당을 조절 할 수 있게 한다[12]. 당뇨병 유발 기전에 있어 PTP1B는 IR를 억제하여 glucose 합성을 증가시켜 체내 혈당을 높이는 작용 
을 한다[24]. 한편 PTP1B를 억제한 쥐에서 insulin 감소 및 체 중증가, 포도당 증가에 대한 저항성을 보이는 연구결과도 보 고 되고 있다[6, 18]. 이렇듯 최근에는 PTP1B를 target으로 한 당뇨치료제들이 개발 중에 있으며 PTP1B의 억제를 통한 항당 뇨 효과를 입증하는 연구가 활발히 진행되고 있다[23]. Akt1은 인슐린 반응과 생육인자 반응에 모두 관여하는 신호전달의 교차점 분자로서 기능성 및 중요성이 복잡한 분자이다[8]. 본 연구에서는 인슐린 신호전달에 중요한 이들 PTP1B와 Akt1의 단백질 발현 수준을 조사하기 위하여 Western blot을 수행하 였다. Fig. 3에서 나타내는 바와 같이 $25 \mu \mathrm{gg} / \mathrm{ml}$ 저농도에서는 인슐린의 작용 PTP1B의 발현을 증가시켰으나, 고농도인 200 $\mu \mathrm{g} / \mathrm{ml}$ 에서는 인슐린의 작용을 억제하여 PTP1B의 발현이 감 소한 것으로 나타났다(Fig. 3B). 비록 in vitro 실험의 한계는 있지만 PTP1B의 발현에 $\mathrm{GBE}$ 가 영향을 준다는 것을 확인하였 다. Akt1는 IR를 통한 신호전달 경로의 중간 분자로서 인슐린 에 의한 신호전달에 아주 중요한 분자이다. 실험에 사용된 HepG2 세포에 인슐린을 24시간 처리하였을 때 Akt1 단백질 발현은 약 $11 \%$ 증가하였으나 $\mathrm{GBE}$ 와 함께 처리한 경우에는 Akt1 단백질발현은 저농도의 $\mathrm{GBE}$ 에 의해서도 감소하는 것으 로 나타났다(Fig. 3C). 이러한 데이터는 GBE가 a-amylase와 a-glucosidase 효소를 억제하지 못하지만 인슐린에 의한 신호 전달과정에 영향을 미친다는 것을 알 수 있었다. 본 연구에서 사용한 시료에는 Rd와 Rg3가 함유되어 있지만 HPLC 분석에 서 C18 column에 부착되지 않고 통과한 여러 물질을 함유하 고 있어(Fig. 1C), 이 실험에서 나타난 PTP1B와 Akt1의 변화가 어떤 물질에 의해서 인지는 밝히지는 못하였다. 그러나, 에탄 올과 같은 유기용매 추출이 아닌 열수 추출된 인삼열매 시료 가 인슐린에 의한 신호전달과정에 영향을 준다는 것이 의미가 있다고 생각된다.

\section{감사의 글}

이 연구는 동의대학교 2012년 교내연구비와 2013년도 (재) 부산테크노파크에서 시행한 산학공동기술혁신사업의 연구비 지원을 받아 수행되었음을 감사드립니다.

\section{References}

1. Allard, M., Schonekess, B., Henning, S., English, D. and Lopaschuk, G. D. 1994. Contribution of oxidative metabolism and glycolysis to ATP production in hypertrophied hearts. Am J Physiol 267, H742-H750.

2. Attele, A. S., Zhou, Y. -P., Xie, J. -T., Wu, J. A., Zhang, L., Dey, L., Pugh, W., Rue, P. A., Polonsky, K. S. and Yuan, C. -S. 2002. Antidiabetic effects of Panax ginseng berry extract and the identification of an effective component. Diabetes 51, 1851-1858.

3. Beckman, J. A., Creager, M. A. and Libby, P. 2002. Diabetes and atherosclerosis: epidemiology, pathophysiology, and management. JAMA 287, 2570-2581.

4. Block, K. I. and Mead, M. N. 2003. Immune system effects of echinacea, ginseng, and astragalus: a review. Integr Cancer Ther 2, 247-267.

5. Brownlee, M. 2001. Biochemistry and molecular cell biology of diabetic complications. Nature 414, 813-820.

6. Gum, R. J., Gaede, L. L., Koterski, S. L., Heindel, M., Clampit, J. E., Zinker, B. A., Trevillyan, J. M., Ulrich, R. G., Jirousek, M. R. and Rondinone, C. M. 2003. Reduction of protein tyrosine phosphatase $1 \mathrm{~B}$ increases insulin-dependent signaling in ob/ob mice. Diabetes 52, 21-28.

7. Hansen, M. B., Nielsen, S. E. and Berg, K. 1989. Re-examination and further development of a precise and rapid dye method for measuring cell growth/cell kill. J Immunol Methods 119, 203-210.

8. Hay, N. 2011. Akt isoforms and glucose homeostasis-the leptin connection. Trends Endocrinol Metab 22, 66-73.

9. Jeon, H., Kim, S. and Jung, N. 1991. Effects of ginseng saponin fraction and cyclophosphamide on the tumoricidal activity of mouse macrophage and the antitumor effect. Korean $J$ Ginseng Sci 15, 99-105.

10. Johnson, T. O., Ermolieff, J. and Jirousek, M. R. 2002. Protein tyrosine phosphatase $1 \mathrm{~B}$ inhibitors for diabetes. Nature Reviews Drug Discov 1, 696-709.

11. Koren, S. and Fantus, I. G. 2007. Inhibition of the protein tyrosine phosphatase PTP1B: potential therapy for obesity, insulin resistance and type- 2 diabetes mellitus. Best Pract Res Clin Endocrinol Metab 21, 621-640.

12. Kulkarni, R. N., Brüning, J. C., Winnay, J. N., Postic, C., Magnuson, M. A. and Kahn, C. R. 1999. Tissue-Specific Knockout of the Insulin Receptor in Pancreatic $\beta$ Cells Creates an Insulin Secretory Defect Similar to that in Type 2 Diabetes. Cell 96, 329-339.

13. Lee, J. and Pilch, P. 1994. The insulin receptor: structure, function, and signaling. Am J Physiol 266, C319-C334.

14. Lee, S. Y., Kim, Y. K., Park, N. I., Kim, C. S., Lee, C. Y. and Park, S. U. 2010. Chemical constituents and biological activities of the berry of Panax ginseng. J Med Plant Res 4, 349-353.

15. Moon, J. Y. 2009. Review on the Current Research of Korean Ginseng for its Antidiabetic Activity. Korean Ginseng Res Ind 3, 19-26.

16. Park, E. Y., Kim, H. J., Kim, Y. K., Park, S. U., Choi, J. E., Cha, J. Y. and Jun, H. S. 2012. Increase in Insulin Secretion Induced by Panax ginseng Berry Extracts Contributes to the Amelioration of Hyperglycemia in Streptozotocin-induced Diabetic Mice. J Ginseng Res 36, 153-160.

17. Saltiel, A. R. and Kahn, C. R. 2001. Insulin signalling and the regulation of glucose and lipid metabolism. Nature 414, 799-806.

18. Sun, C., Zhang, F., Ge, X., Yan, T., Chen, X., Shi, X. and Zhai, Q. 2007. SIRT1 improves insulin sensitivity under insulin-resistant conditions by repressing PTP1B. Cell Metab 6, 307-319.

19. Van Der Maarel, M. J., Van Der Veen, B., Uitdehaag, J., 
Leemhuis, H. and Dijkhuizen, L. 2002. Properties and applications of starch-converting enzymes of the a-amylase family. J Biotechnol 94, 137-155.

20. Wang, C. Z., Zhang, B., Song, W. X., Wang, A., Ni, M., Luo, X., Aung, H. H., Xie, J. T., Tong, R., He, T. C. and Yuan, C. S. 2006. Steamed American ginseng berry: ginsenoside analyses and anticancer activities. J Agric Food Chem 54, 9936-9942.

21. Wang, Y. -J., Zheng, Y. -G., Xue, Y. -P., Wang, Y. -S. and Shen, Y. -C. 2011. Analysis and determination of anti-diabetes drug acarbose and its structural analogs. Curr Pharm Anal 7, 12-20.
22. Wolf, G. 2007. Serum retinol-binding protein: a link between obesity, insulin resistance, and type 2 diabetes. Nutr $\operatorname{Rev} 65$, 251-256.

23. Zhang, S. and Zhang, Z. -Y. 2007. PTP1B as a drug target: recent developments in PTP1B inhibitor discovery. Drug Discov Today 12, 373-381.

24. Zinker, B. A., Rondinone, C. M., Trevillyan, J. M., Gum, R. J., Clampit, J. E., Waring, J. F., Xie, N., Wilcox, D., Jacobson, P. and Frost, L. 2002. PTP1B antisense oligonucleotide lowers PTP1B protein, normalizes blood glucose, and improves insulin sensitivity in diabetic mice. Proc Natl Acad Sci USA 99, 11357-11362.

\section{초록 : 진생베리 열수 추출물의 다당체 분해 효소와 인슐린 신호전달 분자 PTP1B와 AKT1에 미치는 효과}

권은정 ${ }^{1} \cdot$ 홍수경 ${ }^{1} \cdot$ 김문무 $^{1} \cdot$ 김주완 ${ }^{2} \cdot$ 김덕원 $^{3} \cdot$ 정경태 $^{3 *}$

( ${ }^{1}$ 동의 대학교 화학과, ${ }^{2}$ (주바이오포트코리아, ${ }^{3}$ 동의 대학교 임상병리학과)

인삼은 건강에 효과적인 약초라고 알려져 왔다. 인삼의 열매인 진생베리는 인삼의 주성분과 비슷한 ginsenoside, saponin, polyphenol, polyacetylene, alkaloid 등의 성분을 포함한다. 본 연구의 목적은 인삼과 같이 진생베 리 열수 추출물(Ginseng berry water extract, $\mathrm{GBE}$ )이 당뇨와 연관된 세포 외 효소와 인슐린 신호전달 경로에 있는 분자의 발현에 어떤 효과를 가지고 있는지를 조사하였다. a-Amylase와 a-glucosidase는 섭취한 다당분자를 분해 하여 포도당을 생성함으로 항당뇨 약물개발의 표적 효소이다. GBE에 의한 두 효소의 활성 억제능을 in vitro에서 측정하였으나 최고 $1,000 \mu \mathrm{g} / \mathrm{ml}$ 농도에서도 효소활성 억제능이 나타나지 않았다. 인슐린 신호전달 경로의 영향을 확인하기 위해서 HepG2 세포에서 GBE에 의한 인슐린 신호전달 경로의 주요 단백질인 protein-tyrosine phosphatase 1B (PTP1B)와 Akt1의 발현수준 변화를 Western blot 방법으로 조사하였다. 이때 인슐린에 의한 이들 분자의 변화에 $\mathrm{GBE}$ 가 영향을 주는 것으로 나타났다. PTP $1 \mathrm{~B}$ 는 인슐린에 의해 증가된 발현량이 저농도의 $\mathrm{GBE}$ 이 의해 더 욱 증가하였으나, $200 \mathrm{\mu g} / \mathrm{ml}$ 농도의 GBE에 의해서는 다소 감소하는 것으로 나타났다. 또한, Akt1도 인슐린에 의 해 증가된 발현량이 $\mathrm{GBE}$ 농도에 따라 감소하는 것으로 나타났다. 